DOI https://doi.org/10.36059/978-966-397-242-8-11

Yulinetska Yu. V., PhD in Philology, Associate Professor National University "Odesa Academy of Law", Odesa

\title{
LINGUISTIC AND PRAGMATIC FEATURES OF INTERNATIONAL NORMATIVE LEGAL ACT
}

Summary. The proposed study defines the features of international normative legal acts (INLA) as a type of official business text. Attention is paid to the pragmatic and functional approach. The compositional and speech characteristics of INLAs are given. The principles of the linguistic and textual structure are stated. The idea of verbal actualization of the receptive-interpretative (information-interpretative) field of the INLA text is put forward and developed. Such a text is considered as a combination of all the potential meanings inherent in the text corpus, derived as a result of the interpretation. The research determines the components of such receptive-interpretative field. The author explores the relationship between the addresser and addressee factor, and the addresser and addressee information-interpretative fields, respectively. Summarizing the study the role of the category of interactivity to ensure the adequacy of understanding the source text is emphasized.

\section{Introduction}

The increasing need of linguistic research of various international normative documents, in connection with the Ukraine's policy towards the European Union, the desire of our state to become a full member of various international organizations determines the relevance of this work.

Complex linguistic research of the principles and mechanisms of coding and decoding of the text of international normative legal acts (INLA) in their English version, determining the correct interpretation of the original provisions, are the focus of the proposed research. For the first time an attempt is made to systematize those linguistic and extra linguistic means, which allow to correctly interpret the main provisions of the document. In this case, the category of interactivity is considered as the main factor in ensuring the informative-interpretative adequacy of the text at the "output" and "input" of the communication channel. Much 
attention is paid to the mechanisms of coding and primary, i.e. addresser's interpretation of the international normative legal text, as well as to the processes of its perception, understanding and interpretation by the addressee. A significant place in the research is given to specific verbal forms of interpretation, their written fixation in the document itself in the form of various definitions and other interpretive forms - references, analogues, etc.

It is commonly known that the issues of codification and interpretation of various types of text are actively studied within the framework of various philological disciplines, primarily within the framework of general linguistics (or theory) of text, as well as a narrower direction, - text interpretation. The authors of those exclusively stylistic works cannot avoid considering this aspect. Therefore I. V. Arnold's famous book "Stylistics of Modern English" is subtitled "Stylistics of Decoding" [1]. The main tasks and principles of interpretation are formulated in the fundamental works of V. A. Kukharenko, K. A. Dolinin, A. I., Valgina; Van Dijk. A considerable number of publications raise issues of codification and interpretation of specific types of text, in particular scientific and fiction ones [2; 3]. The studies of N. D. Arutyunova [4], O.P. Vorobyeva [5] and other researchers are devoted to a comprehensive study of addresser-addressee correlations.

It should be noted that the theory of interpretation is often identified with hermeneutics: "Hermeneutics, that is the theory (more precisely the process) of interpretation..." [6]. However, as our observations show, the authors of hermeneutic works focus mainly not on linguistic and pragmatic, but on philosophical, political and sociological aspects of text interpretation. [7]. This direction of the study of interpretive processes goes back to the works of F. Schleiermacher, E. Husserl and M. Heidegger [8]. Nevertheless, in this case as well, one cannot do without referring to the linguistic matter itself, which is subjected to analysis with the involvement of the tools of various scientific disciplines.

A study of codification and interpretation issues can therefore be conducted on the basis of already available theoretical provisions and a sufficiently developed terminological system.

However, it should be noted that the focus of most researchers still remains the issues of codification and interpretation of fiction texts. As for official and business texts, only their general features are described in sufficient detail [9]. Of the specific varieties of official and business texts, however, only the texts of some types of military documents, in particular 
orders, have been subjected to a more or less thorough analysis [10]. But even in these works the main attention is paid to structural peculiarities rather than to questions of codification and interpretation correlations. The international normative legal act as one of the types of official and business text was practically not subjected to linguistic and pragmatic analysis. The issues of its interpretation, if considered, were exclusively within the framework of legal research.

\section{Compositional and verbal organization of international normative legal act}

The role of international treaties and agreements in the modern world is difficult to overestimate. Of particular importance is their correct linguistic interpretation, indispensable for achieving mutual understanding between different countries and their representatives and for achieving correct legal interpretative decisions. In the present study, we have tried to fill the gap associated with the lack of comprehensive fundamental linguistic studies of certain types of official and business texts, namely international normative legal acts, by focusing on their codification and interpretation aspects, taking into account the particular importance of their pragmatic component.

The international normative legal act is "an unequivocal agreement between two or more States or other subjects of international law concerning the establishment, modification or termination of their mutual rights and obligations" [11]. The INLA is a typical, most common legal form of establishing cooperation between subjects of international law and can regulate a wide variety of relations between them.

Given the importance of international normative legal acts, or international treaties, as the main source of international law, the UN International Law Commission, even at its first sessions, began to codify the rules relating to international treaties.

Based on the work accomplished by the Commission, the UN Conference on the Law of Treaties was held in Vienna from 1968 to 1969, resulting in the codification of the rules of international law relating to treaties. The Conference elaborated the Vienna Convention on the Law of Treaties [12], which addressed a wide range of treaty law issues. It also provided guidance on how the text of the Vienna Convention on the Law of Treaties should be drafted. 
The 1986 version of the Vienna Convention on the Law of Treaties has been subsequently revised and clarified a number of times and is now used to internationally regulate a wide range of issues [13].

There are no rules in international law regarding mandatory forms of representation of international treaties. In particular, the 1986 Vienna Convention on the Law of Treaties assumes that both written and oral agreements are possible.

However, the written form should be considered typical and is usually used by states when concluding treaties. We will focus our attention in this research on written normative legal acts, as well as on legislative acts that regulate international relations. There are different terms for international normative legal acts: agreement, arrangement, convention, treaty, pact, treatise, protocol, declaration, final act and the like. However, as jurists have pointed out "these distinctions in name have no significant legal significance" [11, p. 202]. This is explained by the fact that the practice of international treaty relations has not developed a general clear criterion for the application of the above terms. The question of naming is decided by the parties to an international treaty.

There is no generally accepted criterion for the classification of international treaties by type [11, p. 202].

In connection with the above, we will not focus on the differences between the individual normative acts, but focus on the general linguistic and content features, which will allow us to identify and outline the main features of the information-interpretive space of this type of text, the text of the international normative legal act.

The INLA is a document designed for long-term use. It is prescriptive and belongs to the category of non-spontaneous, carefully prepared written texts. It is a text with a specific content. Unlike a fictional text, the international normative legal act reflects the real existing reference space, deals with the issues of international legal relations. The text of the INLA can be referred to as neutral message, devoid of emotionality. It is an impartial, detached document based on a clear system of logical constructions, although some of its provisions may be axiological, but this evaluation is rational, rather than emotional.

The mentioned text has a rather rigid internal structure. Despite the absence of a clearly defined volume, the text of the international normative legal act is usually quite an observable document, which facilitates the conditions of work with it for practical purposes. 
The addressee and the addresser of an international legal act are dissociated in space. The transmitting and perceiving the information of such a document are also time separated, which, however, is characteristic of any written text. The international legal act is a result of collective authorship though it is signed by particular persons who are formal addressers of the document, that is completely stipulated within the limits of the existing legal fictions. The text of the international legal act does not have a personal addressee. It is a text intended for all interested parties, which are the signatory states represented by their representatives. However, its specificity lies in the existence of double addressing. In case of disagreements, the relevant issues are to be considered by arbitration (arbitration) courts. In this case the information and interpretation channel becomes more complicated: the ultimate addressee-executor turns from the final interpreter into the intermediate interpreter, and the role of the final interpreter is performed by the representatives of the corresponding arbitration institutions. In the texts of the international normative legal acts, the role of this possible addressee, who, if necessary, must give the final interpretation, is usually stipulated directly in the text of the document:

19. Law and Arbitration

(a) This Charter Party shall be governed by and construed in accordance with English law and any dispute arising out of this Charter Party shall be referred to arbitration in London in accordance with the Arbitration Acts 1950 and 1979 or any statutory modification or reenactment thereof for the time being in force [14, p. 19].

The pragmatic meaning, the illocutionary power (IP) of the international legal act message implies the existence of a prescription, obligatory for all the signatory parties to comply with it. The mentioned IP is transmitted by various linguistic and pragmatic means, though above all by various actualizers of the category of imperativeness, which is an inherent feature of any prescriptive document.

First of all, these include various forms of imperative: the infinitive and infinitive constructions, as well as the modal verb absolute imperative shall (93\% of all cases of imperative constructions in the analyzed international legal acts), used with pronouns and nouns in singular and plural in all three persons:

(1) Article 6. Misuse of Devices

$<\ldots>$ 
2. This article shall not be interpreted as imposing criminal liability where the production, $<\ldots>$ making available or possession referent to in paragraph 1 of this article is not for the purpose of committing an offence established in accordance with Article 2 [15, p. 4].

(2) Article 5

Each State Party shall take such measures as may be necessary to establish its jurisdiction over any of the offences set forth in article $1<\ldots>$ [16, p. 2].

In the case where categoricality gives way to permissibility, the permissive may is used:

(5) The Tribunal may at any time, on the application of a party to the proceedings or of its own motion, order that the proceedings should be heard and in that event may give directions for the disposal of the proceedings in accordance with these Rules.

$[17$, p. 2].

The imperative has not only a direct, immediate mode of expression, but may also be conveyed indirectly. In particular, the verbs of the present tense group in the international legal acts actually acquire the function of a present injunction, losing their literal temporal determinacy. They occur most often in conditional hypotactic adjectival structures, where the main sentence is a deontic statement.

The forms of the future tense, as we have already noted, also acquire modal connotations of oughtness and prescription, which allows us, by analogy with the present prescription, to include them in the group of "future prescriptions:

Article 14

The present convention shall take effect, in the case of the States which have taken part in the first deposit of ratification, one year after the date of the protocol recording such deposit. [18, p. 16].

The Past Indefinite Tense is very rare in the international legal acts (there are, on average, no more than two uses of the Past Tense per 100 sentences). The Past Indefinite Tense can be referred to as the "past of emphasized statement," as is done for strict and semi-strict types of text, when there is an explicit fixation of what is being reported in the written form.

Law is meant to regulate relations between people, institutions, and countries. Linguistic ways of expressing the will and speech realization of the regulatory function of law turn out to be specific stylistic and textforming features. Official and business speech and, accordingly, legal documents bear the connotation of deontiousness, obligation: "Official- 
business style is characterized by imperative, non-personal character, the tone of prescription and obligation" [19, p. 198].

Thus, let us emphasize once again that the prescriptive and obligatory (imperative) meaning is an immanent feature of any international legal act. The dominant actualizer of deontivity is the verb shall. Often linguists focus their attention on the illocutionary component of the communicative act [20]. We mean to emphasize that for texts such as international legal acts, the perlocutionary component is equally extremely important. An international treaty provides for the fulfillment of treaty obligations - otherwise the document has no pragmatic meaning whatsoever. International treaties oblige states that have entered into or have joined them to comply with those agreements.

The principle of compliance with international treaties is formulated in international law as pacta sunt servanda, "the treaty must be complied with". This principle is enshrined in the already mentioned Vienna Convention: "Every treaty in force is binding upon the parties to it and must be performed in good faith" [11, p. 216]. The failure to comply with this principle is considered in modern international law as an international delict (offence). The principle of pacta sunt servanda does not apply to international treaties contrary to a so-called imperative norm of international law, i.e. such a norm "which is accepted and recognized by the international community of states as a norm, from which no deviation is permitted and which can be amended only by a subsequent norm of general international law of the same nature" (principle of jus cogens, p. 53 of the Vienna Convention). [11, p. 216].

The expressiveness of the international treaty, as of any official and business text, is characterized by peculiarity. It does not manifest itself in the presence of emotional and expressive means, but is aimed at the best linguistic realization of the main stylistic features of business speech.

Due to the prescriptive nature of the text of the INLA, it is characterized by a special way of presentation. Linguists usually note the reduction of "modes of presentation" [21] or "functional and semantic types of speech" [22], known in other spheres, to almost nothing in official and business texts. Here it is also impossible to distinguish such, characteristic for the fiction text, compositional and speech forms as narration, argumentation, and description. However, we believe that it would be more accurate to speak about the fact that they are refracted in the international treaties in forms specific to the latter, rather than about the complete absence of these compositional and speech forms. Narration 
corresponds to complexes of statements, argumentation to complexes of arguments. The difference between argumentatives and arguments is the clarity and rigidity of the logically verified constructions of the former, while the formal and logical structure is interspersed with emotionalexpressive and axiological elements in fiction text's reasoning.

It should be emphasized once again that the argumentatives in the international treaty, just as in any other official and business text, are built exclusively on formal-logical principles, with a very limited use of axiological means or markers.

The statements (or confirmativas) are also without evaluative and emotive connotations. That is how they are principally distinguished from narrative structures in the fiction text. At the same time, the statements in the international treaty are accompanied by a large number of conditional sentences, which specify and often limit the scope and application of the corresponding propositional clauses.

The main sphere of application of statements is in the so-called affirmative parts of the document. The constatives are almost devoid of implicative potential. They are usually completely open, explicit propositions that do not require any complex operations to extract meanings. For example:

Article 1 - Protection of property.

Every natural or legal person is entitled to the peaceful enjoyment of his possessions.

[22, p. 1].

or

Article 3

The High Contracting Parties undertake to hold free elections at

reasonable intervals by secret ballots, under conditions which will ensure the free expression of the opinion of the people in the choice of the legislature [22].

The fragments similar to descriptive contexts appear in the international treaty in a special prescriptive-constitutive way of presentation. These are mainly definitions and other components of interpretative units.

At the same time, it can be argued that there are fragments in the international treaty, which contribute to talking about a special, specific to any INLA compositional and speech form, associated with the implementation of the main pragmatic function of these documents - the prescriptive-obligatory one. 
The analysis of the texts reveals that there are grounds to distinguish in the structure of international treaty the imperative-prescriptive compositional speech form, which is represented by imperatives, permissives and prohibitives. Moreover, these are not individual instances, but predominantly entire text units, numbering up to 50-60 sentences.

For example, in the established "Hague Rules" (International Convention for the Unification of Certain Rules Relating to Bills of Lading, Brussels, 25 August 1924), we find that almost all articles, from the second to the sixteenth, are represented by the said compositional speech form. All the provisions are strung on the pivot of the modal verb shall.

We have already emphasized on other occasions the prescriptive and obligatory nature of the international treaty. Therefore, the most important linguistic and stylistic feature of such a text is the predominant number of sentences used to achieve maximum transparency and the most precise fixation of meaning.

The accuracy of the wording of legal norms and the need for absolute adequacy of their understanding by the addressee is the ultimate goal to which the authors of international treaty must tend. The regulatory function of the international legal act is ensured by this precision alone. On the contrary, "the vagueness of these formulations, the assumption of ambiguous interpretations prevent the implementation of the basic function of law, destroy its immutability and authority" [21]. Accuracy, which does not allow ambiguity, is manifested primarily in the use of special terminology, as well as in the unambiguity and impersonality of non-terminological vocabulary. The search for accuracy limits the possibilities of synonymic substitutions in acts, since the latter usually cause changes in the nuances of meaning. Therefore, an inherent feature of this type of text is the high repetition of the same words, which is manifested in the indicators of their frequency: the key words of the document are repeated between 20 and 48 times. Accuracy is facilitated by various clarifications and reservations, leading to the widespread use of colloquialisms, especially participatory ones, as well as the use of adjectives, especially conditional sentences, and the predominance of conjunctions over non-conjunctions. These features can be demonstrated by the following:

1. A party may, within the limits of its domestic law and without prior request, forward to another Party information/ obtained within the framework of its own investigation /when it considers/ that the disclosure of such information might assist the receiving Party in initiating or carrying out investigations or proceedings concerning criminal offences established 
in accordance with this Convention or might lead to a request for cooperation by that Party under this chapter. [15, p. 14].

As we note, this clause from Article 26 is a complex syntactic construction with two conditional and additional subordinate clauses, two participial clauses (the main word of the first is obtained, the second is established), and an explicit conjunction between both sentences (when, that) and homogeneous members of a sentence (and, or).The conditional structures may have a framework character:

Article 4

If any such goods shipped with such knowledge and consent shall become a danger to the ship or cargo, they may in like manner be landed at any place, or destroyed or rendered innocuous by the carrier without liability on the part of the carrier except to general average, if any. [18, p. 13].

The correlation of conjunctive and non-conjunctive structures, as our figures have shown, is 3.5:1 in favor of the former. In general, the multiplicity of restrictive and concretizing means leads to a significant increase in the size of the sentence, including the simple one, up to several hundred word uses (50 - 200 words). For example, in the Congenbill of lading (1978), some articles are represented by a single extended sentence of more than 100 words. Thus, Article 6 of this document contains 146 words. Certain paragraphs of the articles are represented by a single extended sentence. Thus, paragraph 7 of Article 3 of the same agreement consists of 139 words. The average length of a sentence in the international treaty, as the analysis revealed, is 17.6 words. Regulation and relative strictness of the construction is manifested in the fact that there are a number of rules or principles of presentation for the texts of normative legal acts, which are generally referred to as the technique of presentation of legal norms. In particular these include:

- sequence of presentation;

- narration simplicity (a principle which is not followed in practice because there is a demand for a maximum explication of the meaning);

- thematic homogeneity of the content;

- avoidance of contradictions;

- correspondence of the content of the law to its denomination;

- exclusion of occasional "blanks", i.e. provisions left without interpretation or explanation, the use of referential articles to this end.

In general, the text of an international legal act often contains rather complex legal concepts. Therefore, the addressee, while pursuing maximum precision and accuracy in the use of legal terms, simultaneously 
seeks to be understandable, simple, and clear in its presentation. Nevertheless, to achieve this, he sometimes has to overcome some conservative rules providing for the use of archaic and clerical vocabulary, which introduces ambiguity or semantic confusion into the text.

Hence, the peculiarities of the legal sublanguage are clarity, conciseness, certainty and accuracy of the message, the imperative nature of the statement, the wide use of special terminology and clichéd expressions.

Since in legal relations everything is regulated and communication is carried out according to certain standards that facilitate this communication, then a speech standard, a pattern appears here inevitable, necessary, reasonable and justified. As N.S. Valgina observes correctly, "the standard form is the most important detail of the literary appearance of a given type of writing" [19, p. 197].

\section{Category of interactivity and particularities of its actualization in international normative legal act}

The final text of international legal act can be considered the published version of the text, i.e. the text, which has passed both initialing (preliminary signing) and promulgation.

The official addresser of the international treaty are considered first and foremost the states represented by their heads, though the functions of the official addresser can be delegated to the representatives of other state structures or institutes as well.

However, the official signatories of the international treaty are legally fictitious authors. In reality, the document is prepared by special bodies, committees and commissions, employees of sectoral institutions, etc. This specificity of the addresser is also reflected in the linguistic sphere itself. The message in the form of the international treaty comes from the addresser, a figure of a particularly generalized, abstract character. In the text, this causes a grammatical weakening of the forms of the person, which is expressed in the meanings and functioning of the corresponding linguistic units - primarily the verb and personal pronouns. Thus, another feature of this type of text is its impersonal or limitedly personal nature. The signatories of the international treaty usually speak about themselves in the 3rd person, emphasizing the most objective nature of the provisions presented. For example:

The Member States of the Council of Europe, signatories of this Convention, $<\ldots . .>$

Have agreed as follows: $<\ldots>[16$, p. 2]. 
The specificity of the addresser factor in the international treaty is that the addresser is not an ordinary producer of information, which must be interpreted by the addressee, i.e. its recipient, but acts in two hypostases: he is both the sender of information and its primary interpreter. Thus, the text creates a single information-interpretative field of the addresser (IIFa1), the informative elements of which are closely integrated with the elements of interpretative potential.

It is worth noting that in linguistic works, the concept of the interpretive component appears only when considering the addressee's module (or factor). In fact, the interpretive component is an immanent feature of the addresser's module as well.

We introduce the qualifier of the interpretive component in order to emphasize that one of the components of this space is the interpretive component. In our opinion, the term "information-interpretive field" is more accurate than the term "information field". There are a considerable number of elements in a single IIFa1 that can be called interpretive reference points, which help the addressee to perform the correct interpretive operations. At the same time, they are integrated completely into the informative array itself, being its ingredient component.

The international legal acts also include special interpretative propositions or provisions, which are combined into entire interpretative units, the main function of which is to provide the author's interpretation and thereby relieve the addressee from performing numerous formal and logical operations to draw the necessary meanings. In this case, the addressee is presented with ready interpretations, which he has to understand and then correctly formalize and record in the corresponding interpretive documents. Despite their relative autonomy, they are nevertheless closely related to the information parts that these units are meant to explain. This coherence is actualized through the repetition of key terms, which are interpreted in the interpretive parts and then become the semantic support of the proper factual part of the document.

At the same time the interpretational layer does not completely cover the entire content-factual sphere of the message - there are always certain areas in the text of the international treaty, which remain within the discretion of the addressee, who performs the role of the secondary interpreter of the international legal act text.

Thus, the information-interpretative field of the addressee (IIFa2) can also be distinguished in the text of the international treaty: this field, however, has a powerful extralinguistic component, which is 
extrapolated to the texts that represent the written record of interpretative decisions, such as judicial decisions. Verbal fixation of the results of the recipient's thought operations is obtained verbally or in other documents only, in which the relevant interpretative decisions become the basis for the decisions of international tribunals, courts, etc., which in this case are the final collective addressee and interpreter of the information of the international treaty.

In this regard, we should emphasize a particular role of the perlocutionary power of texts of this type. Indeed, the intended recipients of such documents are specific executors - representatives of all the signatories of the international treaty: various institutions, bodies that are directly affected by the provisions of the document, i.e. the so-called "persons concerned". Provided there are no legal conflicts, they are the addressees-executors, the main and final interpreters of the source information. The indirect addressees are international tribunals, courts, and arbitration bodies, which, in the event of legal conflicts, take on the functions of the final interpreter and make decisions on contentious issues, while the direct executors play the role of an intermediate interpreter.

The misinterpretation of the source text of the international treaty, as we know, leads to judicial mistakes that can affect the fate of both individuals and entire states, so the perlocutionary component is of particular importance here.

At the first stage, the addressee performs mental operations, engaging in inductive and deductive procedures. Then the results of this work are reflected in secondary documents, where they become the starting point for the corresponding particular legal actions.

Therefore, the coincidence of the maximum number of areas of information-interpretation fields of the addresser and the addressee is especially important for the interpretative and semantic adequacy on the "output" and "input" of the information-interpretation channel. Obviously, their boundaries cannot coincide completely in reality, but a considerable degree of convergence and extensive overlapping is quite achievable, especially when the number of interpretation sections or units proper is large.

The addresser of the international treaty encodes information, and this is done in as explicit a form as possible. Moreover, as we have already noted, he largely "frees" the addressee from the need to conduct complex operations of information decoding, introducing into the text interpretative linguistic-compositional guidelines and ready 
interpretative propositions. Accordingly, the addressee has a reduced number of possible interpretations of the presented information. The area of his independent interpretive decisions is significantly reduced due to the extensive and very active addresser's component. However, this non-self-sufficiency of the addressee can be considered a strong point of the information-interpretation space of the international legal act: it allows to minimize the differences at the "output" and at the "input" of the IEC message, which is the text of the international treaty.

The direct addressee is the performer of instructions and prescriptions of the addresser, who sets the vector of interpretation. The author of the fiction text, codifying the information, leaves to the addressee a large degree of choice, allowing him to give his own interpretations and even to find in the subtext what the author did not mean, but which he does not object to at all.

In the case of the international treaty, such freedom of interpretation would lead to the failure of the main pragmatic function of the document: the addressee, interpreting the information presented incorrectly, may perform legal actions not expected of him, i.e. it is likely to deviate from the originally intended perlocutionary effect, which, in turn, may lead, as we have noted, to the aggravation of international controversies and complication of the international situation in general.

In order for the addressee to interpret the relevant information correctly, it is necessary to find points of agreement of a cognitivepsychological nature between the addresser and the addressee. That is why the category of interactivity is so important for achieving the adequacy of addresser (primary) and addressee (secondary) interpretation. What is the essence of the principle of interactivity?

"Interactivity as a textual-discursive category is represented by the subject-object-subject interaction of communicants <...>. The psychological basis of interactivity is the desire to be understood and to understand the other $<. . .>$. The cognitive basis is a certain commonness of the spheres of consciousness, $<\ldots>$ thesauruses of the communicants, the mechanisms of association. The linguistic basis of interactivity is the speech system, the purpose of which is the realization of communication". [8, p. 234].

Within the framework of communicative activity, the text-forming action of the author is always stimulated and guided by a clearly expressed attitude towards the maximum possible complete 
communication of the author's intention to the recipient, in order to achieve the maximum degree of its understanding by the recipient.

A natural consequence of such an attitude is the author's intention to use such content and structure of the intended text, as well as such means of language for their expression, which in combination would be accessible to the understanding of the recipient, to whom the text is addressed.

The recipient's conceptual system (CS) [23] determines the amount and content of knowledge the recipient has about the actual or possible world. In the absence of sufficient "overlap" of the recipient's knowledge and new information, the latter will be rejected. On the other hand, if all the information the text carries is already contained in the recipient's CS, then such a text is not interesting for him, - it does not stimulate the recipient to perceive the text.

If the author believes that some information should be known to the recipient, it can only be named or labeled.

The addresser's cumulative representation of the recipient's CS, his knowledge, on the one hand, and the complexity/simplicity of the content to be represented determines the text structure and the nomenclature of the elements that provide intratextual connections. The structure of the text should ideally be in "inverse" dependence on the complexity for the recipient of the content model objectified in the text.

Accordingly, interactivity involves the presence of a common background of knowledge, perceptions, which makes it possible to find points of agreement between the addresser and the addressee, providing conditions for communicative interaction to take place. Through interactivity, the addressee can relate linguistic expressions to the same images and objects as the speaker.

Interactivity is closely related to referencing, i.e. "the attribution of actualized names, nominal expressions or their equivalents to the objects of reality" [22, p. 121]. In order to ensure that the addressee understands the source message adequately, it is necessary for the addresser and the addressee to define the referential relation of objects and concepts in the same or almost the same way.

If the objects of reference remain unknown for the addressee, i.e. interactivity is not reached, then the adequacy of the addressed understanding and the addressed interpretation is not provided. That is the reason why it becomes so important to bring the referential bases of the addressee and the addressee to a common denominator in order to preserve interactivity. In the international legal act this is usually done, 
as we have already noted, by expanding the area of elements of the author's interpretive potential. In the case of the international treary the area of intersection of conceptual fields, on which the corresponding information-interpretive fields of the addresser and the intended addressee are constructed, is large enough due to the fact that both are mostly specialists in the field of political and juridical sciences.

The information-interpretational field is defined as a combination of all explicit and implicit meanings, which provide in a textual array a sphere of discretion of an addresser or an addressee.

The universal textual information-interpretative field is represented by the information-interpretative fields of the addresser and the addressee.

Consequently, the information-interpretive field of the addresser and the information-interpretive field of the addressee represent in their integrity and interaction the common information-interpretive space (IISp) of the explicit text of the international treaty and its implicatures. However, this ratio is not the same in different texts. Whereas for a fiction text the bias towards implicatures is quite justified and to a certain extent testifies to the skill of the author, in official and business texts, including INLAs, explicatures must dominate, otherwise the success of the main pragmatic task remains questionable. A technical definition of "explicitness" is suggested by Sperber and Wilson: "the content communicated by an I statement is explicit, if only it is a manifestation and development of the logical form expressed in I by means of a linguistic code" [24, p. 182]. Explicatures provide formal-logical inferences, i.e., simple semantic consequences.

Implicature implies probabilistic inferences, the mechanism of formation of which has not yet been fully explored. As J. Fodor notes, there is as yet no psychologically adequate theory of this complex process [22, p. 127].

Levinson also writes about these difficulties: "Implicatures are not logical inferences and cannot be modelled in terms of semantic relations" $[19$, p. 115-116].

Implicatures, according to Grice [25], are intended to contribute to a better description of the non-letter aspects of meaning and meaning that are not directly determined by the conventional structure of language expressions, that is, what is implied, what is alluded to.

In international treaties, explicatures are of primary importance, and conditions for the emergence of implicatures are sometimes deliberately created so that the addresser can interpret the propositions on his or her behalf. Generally, they are possible when interpreting those provisions that 
are deliberately left to the addressee's discretion. However, in general, implicatures have a limited scope of application in the international treaties. This is due to the fact that the implicature is not conventional - it is not calculated, as we have already emphasized, directly from linguistic realities, it is not given in a particular form and has a very indefinite nature, which deprives the message of the necessary perlocutionary force.

Obviously, we should agree with the following point of view: "since we do not know the speaker's intentions, the degree of his interest and sincerity, any inference of implicatures from a fragment of communication gets the epistemic status of introspective interpretations. In this case, even metaphorically, it is at least not correct to talk about the calculation of implicatures" [22, p. 131].

Nevertheless, the interpretation of the text of the international treaty and the interpretation of lexical meanings are not only limited to the recognition of explicatures, but also involves the analysis of implicit meanings.

We should emphasize again that in different types of text the ratio between explicatures and implicatures varies. In the texts of normative legal acts, including international treaties, this ratio is characterized by a significant predominance of the former over the latter, which is confirmed by the so-called "Golden Rule of Interpretation," which provides for interpretation based on literal meanings, unless it leads to absurdity, to the violation of some basic logical laws and postulates [12].

\section{Peculiarities of presupposition in international normative legal act}

Two approaches to the interpretation of any text can be discussed. Interpretation can be understood as: 1 ) a process, certain procedures, the extraction of presuppositional meanings, which involves carrying out various logical operations, the extraction of implication, various types of deductive and inductive inference; 2 ) a result of logical order operations, the fixation of the result of this process in the form of completed propositions and definitions.

We will examine interpretation in more detail as a process and, above all, as the extraction of presuppositional meanings.

The term "presupposition" was proposed by Frege as early as 1892 [26]. As a semantic and pragmatic term, presupposition is interpreted in different ways. Sometimes it is mixed up with explicature disclosure operations, sometimes with semantic implicature. From the textocentric point of view, presupposition is treated as a special case of inference - as a conclusion deduced from a given statement according to the rules of truth or relevance. 
The communicatocentric approach implies the treatment of presupposition as a precondition for the realization of the statement.

We believe, following Makarov, that presupposition is a semantic component of a statement, the truth of which is necessary so that the given statement a) is not semantically anomalous (semantic presupposition); b) is appropriate in a given context (pragmatic presupposition) [22, p.133].

Semantic presupposition is a special kind of semantic consequence. Statement $\mathrm{P}$ is considered to be a semantic presupposition of statement $\mathrm{S}$ if it follows from both the truth and the falsity of $\mathrm{S}$ that $\mathrm{P}$ is true. Thus, if there is a statement The jury returned the verdict, then one of the semantic presuppositions is The jury exists. The statement remains true even in the case of negation: The jury didn't return the verdict.

Semantic presupposition is not affected by epistemic and modal operators.

Semantic presuppositions are not overwhelmed by context, they have the feature of non-defeasability and are conventional in the sense that they are assigned to linguistic units out of their actualization.

There are centential operators that let all presuppositions through the so-called holes, those that do not let them through - plugs, and filters, sometimes letting the original presuppositions through, sometimes not.

Thus, presuppositions appear to be connected in a sentence with certain words or some elements of syntactic structure, which gives grounds for distinguishing lexical and structural presuppositions, while these linguistic means themselves are called presupposition activators (presupposition-triggers) [27, p. 179].

Pragmatic presupposition in its broadest sense is understood as the relation between the addresser and the appropriateness of a statement in context [27] according to the formula: $\mathrm{P}$ is a pragmatic presupposition of a statement $S$ if whenever the statement $S$ is communicatively appropriate, the author of statement $S$ believes that $\mathrm{P}$ is true and believes that its addressee also believes that $P$ is true [27, p. 387].

In this definition, as one can see, the interactive component of presuppositional constructions is sufficiently clear.

In other words, the presuppositional field is that area in which there is a minimum amount of divergence between the primary (addressed) interpretation and the recipient's interpretation of information.

Indeed, for the success of communication, understanding and correct interpretation the common cognitive fund of the addresser and 
addressee is necessary, i.e. "participants in the phenomenological field should have a common set of context propositions - a common presuppositional fund, otherwise their joint activity of discourse generation and understanding is difficult or simply impossible due to interactivity violation" [22, p. 137].

Pragmatic presupposition can be understood as a number of propositions assumed by the addressee as to what the addressee is inclined to accept on faith, i.e., without objection. Grice calls sentences of this nature "non-contradictory information" [25, p. 190].

In psychological terms, this corresponds to a complex set of attitudes, expectorations and anticipations. Anticipation refers to the addresser's psychological attitude to the recipient's reaction, while explication refers to the addressee's psychological attitude, his or her readiness to accept information without objections or doubts (without challenge).

The most important feature of normative acts, including international treaties, is that many of their presuppositions are explicit, which further narrows the possibilities of divergences in the understanding and interpretation of the addresser and the addressee.

Indeed, in the sentence "The jury formed returned the verdict" the word formed is clearly redundant - it is easily inferred from the situation: if there is a jury (jury trial), then it must have been formed at a previous stage.

Nevertheless, there are quite a few such redundancies in English legal documents. In this form, they tangibly help the recipient, who has any failures in the mechanisms of logical information processing. A peculiar system of double presuppositional "protection" is created, when the presupposition is verbalized and introduced into the context. It is as if the author insures the addressee-interpreter, prevents him from deviating from the course set by the addressee.

A specific feature of the international treaties, as well as of all normative acts, is the existence of the so-called legal fictions in them. In fact, these are artificial presuppositions, created in a conventional way, i.e., on the basis of a special agreement.

Thus, the specificity of legal texts is that along with natural presumptions there are also conventional presumptions, known as legal fictions.

Legal fictions are conventionally accepted provisions, assumptions about the existence of something that does not exist in reality:

"fiction [is] an assumption that something is true irrespective of whether it is really true or not". 
Thus, for example, legal fictions are so-called legal persons. Indeed, a legal entity is regarded as an independent and actually existing subject of law. It is considered that the existence of a legal entity and the actions performed by it do not depend on real people (or physical persons). But it is clear that without people themselves legal persons cannot exist and act. Thus, the existence of legal persons is a conventional presumption: background knowledge conditioned not by the real experience of communicants, but by their agreement, in this case prompted by professional considerations.

Hence, "legal fictions in law provide an opportunity to consciously take as really existing such actions or events which in fact did not exist, do not exist, and could not be" [28, p. 88].

The use of legal fictions allows using conventional forms of interpretation, i.e. forms recognized by the parties after specific agreements are reached.

An exemplary legal fiction, as we have already noted, is the meaning of the word person, when it becomes a designation of a legal entity, i.e. not only an individual, but also an entire organization or institution acting as a subject of legal relations: "person" includes (in addition to an individual) any body of persons corporate or unincorporated.

The legal fiction is represented by the meaning of the word "party," which can actualize not only the concept of "community", but also the concept of "individual".

Therefore, such seemingly illogical expressions as in case of this party's death become possible in the international treaty, as well as in other legal documents. It is absolutely clear that only an individual can die, and not a "party" in the case, nevertheless the wording is legally valid.

The addresser does not need to specify each time the meaning of the word party in the international treaty, since any professional lawyer understands what he is talking about - for such an addressee everything comes down to the extraction of purely presumptive meanings, which are known to him by virtue of a once-existing agreement between different representatives of the legal profession.

We shall consider the logical and verbal specifiers in the international normative legal act as a considerable number of ways of specifying normative provisions are available in INLAs. In particular, restrictive structures are widely used. Those restrictive constructions have various structural and syntactic models of actualization. Most of them are conditional clauses, introduced by conditional conjunctives if, provided, 
unless, etc: The Vessel to be delivered not before the date indicated in Box 14 unless with the Charterer's consent [29, p.11]. These also include exclusion structures with the indicators exclude, excepting, except:"Goods" includes goods, wares, merchandise, and articles of every kind whatsoever except life animals and cargo which by the contract of carriage is stated as being carried on deck and is so carried [18]. The logical and verbal means of specification, which provide a significant narrowing of the number of options for interpretation and focus the interpretive activity in the right direction, also include expansive constructions of inclusion with the indicators include, including: "Carrier" includes the owner or the charterer who enters into a contract of carriage with a shipper [18].

Therefore, various logical and verbal qualifiers are instrumental in understanding the normative clause properly. The large number of different clauses leads to a significant number of conditional constructions (up to $43 \%$ of all hypotactic structures in the INLAs).

The need to specify the scope of a concept and the scope of a normative provision leads to an increase in the number of inclusion and exclusion constructions. The specification of subjects and objects is carried out with the help of determinative clauses (32\% of all hypotactic structures), as well as various descriptive clauses.

\section{Conclusions}

1. International normative legal act (INLA) is a text of medium-strict type: it is structured according to rather rigid regulations and rules, deviations from which may lead to its qualification as a legally void document.

2 . The mentioned rules are predetermined by the pragmatic focus of the INLA: it is a text of prescriptive nature, that determines its leading illocutionary function - to influence the addressee in order to perform certain legal actions by the latter. This is a document, based on the imperative, which determines its main pragmatic message as a directive instrument. The perlocutionary effect is achieved when the addressee begins to follow the instructions and indications which are initiated by the addresser.

3. The illocutionary function of the INLA is also determined by the specificity of the information coding: it should be presented in a maximum explicit form, and the ambiguity is qualified as a disadvantage of this type of text. It is the unambiguity and transparency of the wording that allows specifying the vector of interpretation, which leads to the only appropriate reaction of the addressee and makes him comply with the instructions prescribed by the addresser. In other words, the elimination 
of ambiguity is the only way to achieve full compliance of perlocution and illocution, otherwise the practical sense of any decision-making document, including the international normative legal act, is lost.

4. Information adequacy on "output" and "input" of the informationinterpretation channel is possible as long as there is a considerable vast area of overlapping of the addresser's and addressee's informationinterpretation fields, which is formed as a result of the increasing role of the addresser's component and its explicit representation.

5 . The distinctive feature of the INLA text is that the author of the INLA is both the sender of information and its primary interpreter, who sets a clear interpretative vector for the addressee.

6 . The addresser encodes the information in the INLA text in such a way as to introduce the maximum possible number of interpretative reference points or indicators, which help the addressee in decoding the text and extracting the meanings embedded in it.

7. The mentioned indicators include, in particular, regulating textual delimitation indicators (demarcators or volume-pragmatic division markers), which contribute to structure the text correctly in order to accelerate the process of perception and understanding of the INLA information by the addressee.

8. Numerous connectors perform an important orientation role, allowing to indicate the correlation of various provisions of the document, to establish their correlation and interdependence, to build them into a clear hierarchical sequence with varying degrees of detail. The most frequent ones include the additive connector and, the disjunctive or and the contradictive element but, which in the INLA text acquire greater semantic capacity than in other types of text, and are distinguished by significant recurrence within a single sentence, contributing to the discrete representation of correlated objects or phenomena, providing the necessary level of detail of the relevant fragments of reality.

9. The specific nature of the INLA is the existence of extensive units of interpretation, that are usually not present in the texts of the fiction type, which allows the author to remove the undesirable ambiguity and uncertainty of the information presented, specifying the content and factual component of the INLA to the utmost.

10. The impact of the addresser's powerful information-interpretative field significantly narrows the addressee's interpretative component, thus the addressee is able to manifest his creative interpretive independence exclusively within the limits strictly specified by the addresser. 


\section{References:}

1. Арнольд I. В. Стилистика. Современный английский язык. Москва, 2016. 384 с.

2. Колегаева И. М. Текст как единица научной и художественной коммуникации. Одесса, 1991. 121 с.

3. Мизецкая В. Я. Композиционно-речевая организация драматургического текста: на материале англоязычных пьес XVI - XX вв. Одесса, 1992. 501 с.

4. Арутюнова Н. Д. Дискурс. Лингвистический энциклопедический словарь. Москва, 1990. С. 136-137.

5. Воробьева 0. П. О таксономии адресата художественного текста. Текст и его категориальные признаки. Киев, 1989. С. 39-46.

6. Квіт С. Основи герменевтики. Київ, 2003. 192 с.

7. Рикёр П. Конфликт интерпретаций: очерки о герменевтике. Москва, 1995. 416 с.

8. Селиванова Е. А. Основы лингвистической теории текста и коммуникации. Київ, 2002. 336 с.

9. Валгина Н. С. Теория текста. Москва, 2004. 280 с.

10. Нелюбин Л.Л. Перевод боевых документов армии США. Москва, 1971. 335 с.

11. Большой англо-русский словарь: в 2 т. / под рук. И. Р. Гальперина. Москва, 1972. Т. 1.822 с., Т. 2.863 с.

12. Vienna Convention on the Law of Treaties between States and International Organizations or between International Organizations. $34 \mathrm{p}$. URL: http://fletcher.tufts.edu/multi/texts/BH883.txt

13. Protocols to Vienna Convention on the Law of Treaties between States and International Organizations or between International Organizations. 34 p. URL: http://fletcher.tufts.edu/multi/texts/BH883.txt

14. Charter “Gencon”. 24 p. URL: https://www.bimco.org/contractsand-clauses/bimco-contracts/gencon-2021

15. Convention on Cybercrime. 24p. URL: http://www.inter.criminology.org.ua/jetspeed.eng/materials/english/l aws/cibercryme.ht

16. International Convention Against the Taking of Hostages. G.A. Res. 146 (34), U.N.GAOR, Supp.№ 46, at 245, U.N.Doc. A/34/46. 2019. 22 p. URL: http://www.undoc.org/undoc/terrorism_convention_hostages.html

17. The Lands Tribunal Rules. Parts 1-4. 57 p. URL: http://www.hmso.gov.uk/ si/si/1996/Uksi20061022en 1-9.htm 
18. Bill of Lading. Code name: "Congenbill", edition 2016. URL: https://www.bimco.org/contracts-and-clauses/bimco-contracts/ congenbill-2016 26p.

19. Валгина Н. С. Теория текста. Москва, 2004. 280 с.

20. Шевченко И. С., Морозова Е. И. Дискурс как мыслекоммуникативное образование. Вісник ХНУ. 2003. № 586. С. 33-38.

21. Кожина М. Н. Стилистика русского языка. Москва, 1977. 223 с.

22. Макаров М. Л. Основы теории дискурса. Москва, 2003. 280 с.

23. Каменская О. А. Текст и коммуникация. Москва, 1990.152 c.

24. Wilson D., Sperber Inference and Implicature. Meaning and Interpretation. Oxford, 2006. P. 43-75.

25. Grice H. P. Logic and Conversation. Syntax and Semantics. Speech Acts. New York, 1975. P. 41-58.

26. Фреге Текст и коммуникация. Москва, 1990.152 с.

27. Levinson S. Pragmatik. Tubingen, 2000. 476 p.

28. Романов А. К. Правовая система Англии. Москва, 2002. 344 с.

29. The Helsinki Convention on the Protection of the Marine Environment of the Baltic Sea Area (entered into force in 2000). 13 p. http://www/helcom.fi/print/helcom/convention.html 